\title{
Acute Genital Ulcers in a Virgin Adolescent Girl: A Case Report and Literature Review
}

\author{
Virjin Adolesan Kızda Akut Genital Ülser: \\ Bir Olgu Sunumu ve Literatür Taraması
}

\author{
Hüseyin Çivici', Serhan Can İșcan², Jalal Raoufi², Evrim Erdemoğlu² \\ 'Süleyman Demirel Üniversitesi Tıp Fakültesi, Kadın Hastalıkları ve Doğum Anabilim Dalı, Isparta \\ ${ }^{2}$ Süleyman Demirel Üniversitesi Tıp Fakültesi, Jinekolojik Onkoloji Bilim Dalı, Isparta
}

\begin{abstract}
Acute genital ulcer (AGU) is a painful ulceration of genitalia that presents in especially virgin young women. The differential diagnosis includes venereal (sexually) and non-venereal (non-sexually) transmitted infections, non-infectious diseases, drug reactions, autoimmune conditions, traumatic causes and malignant. However, etiology and pathogenesis of AGU are still unknown. The disease is characterized by an acute onset of flu-like symptoms such as anxiety, fever, myalgia, pharyngotonsillitis, lymphadenopathy, and headache, with single or multiple, deep and painful mainly kissing ulcers on the vulva, on the inner side of labia majora. Ulcers associated with an immunologic reaction to a distant source of infection or inflammation. The aim of this article is to present a case of acute genital ulcer and discuss for documenting the natural history of AGU, as well as making a diagnosis, differential diagnosis, and treatment options.

Key words: Acute genital ulcer, ulcus vulvae acutum, Lipschutz ulcer, Virgin
\end{abstract}

\section{Öz}

Akut genital ülser (AGU) özellikle virjin genç kadınlarda ortaya çıkan genital ağrılı bir ülserasyondur. Ayırıcı tanıda cinsel yolla geçen bulaşıcı enfeksiyonlar ve cinsel yolla geçmeyen bulaşıcı enfeksiyonlar, enfeksiyöz olmayan hastalıklar, ilaç reaksiyonları, otoimmun durumlar, travmatik nedenler ve vulvar kanser vardır. Bununla birlikte, AGU'nun etiyolojisi ve patogenezi hala bilinmemektedir. Hastalık anksiyete, ateş, miyalji, faringotonsillit, lenfadenopati ve baş ağrısı gibi grip benzeri semptomlar ile akut başlayan, vulvada, labia majör iç kısmında, tek veya çoklu, derin ve ağrılı genellikle birbiri ile öpüșen ülserler ile karakterize bir hastalıktır. AGU özellikle uzak bir enfeksiyon ve inflamasyona kaynağına sekonder bir immünolojik reaksiyon ile ilișkilidir. Bu yazının amacı, akut genital ülserin doğal seyrini göstermek, tanı koymak, ayırıcı tanıları belirlemek ve tedavi seçenekleri sunmaktır.

Anahtar kelimeler: Akut genital ülser, Ulcus vulvae acutum, Lipschütz ulseri, Virjin

Yazışma Adresi / Correspondence:

Dr. Hüseyin Çivici

e-mail: huseyincivici@sdu.edu.tr

Date of submission: 02.12.2018

Date of admission: 16.04.2019

\section{Introduction}

Lipschütz ulcer, also known as acute genital ulcer, acute vulvar ulcer or, ulcus vulvae acutum refers to a painful ulceration of genitalia. Lipschütz ulcer is a non-venereal disease that presents in especially virgin young women. Acute genital ulcer (AGU) is a rare condition that the clinicians may sometimes underdiagnose and even misdiagnose with other entities. ${ }^{1}$ The aim of this article is to present a case of AGU and discuss pathogenesis of AGU and treatment options. We have also made a literature review of AGU. 


\section{Case Report}

A 15-year-old virgin girl was referred with acute painful genital ulcers for first time in her life (Figure 1). She had swelling and inflammation in mainly inner side of left labia majora and a little lesion on the right side and she complained of fever and severe headache since one week (Figure 2). Antiviral therapy (acyclovir) was started at an external center before she was admitted. However, the ulcerative lesion became greater, fever and edema increased despite antiviral therapy. In her past medical history, she had no recurrent genital or oral aphthous lesions.

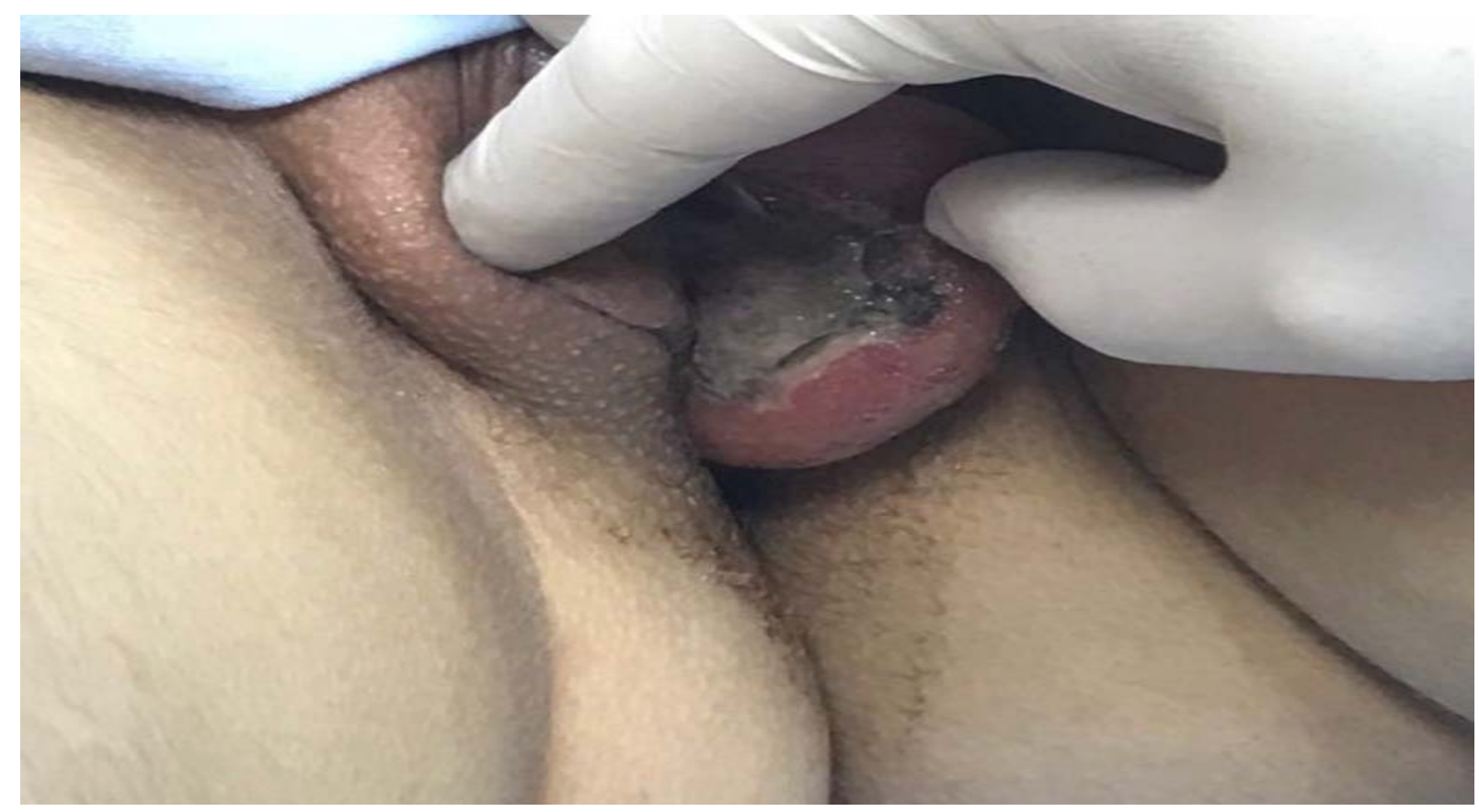

Figure 1. Acute painful genital ulcers in the first examination

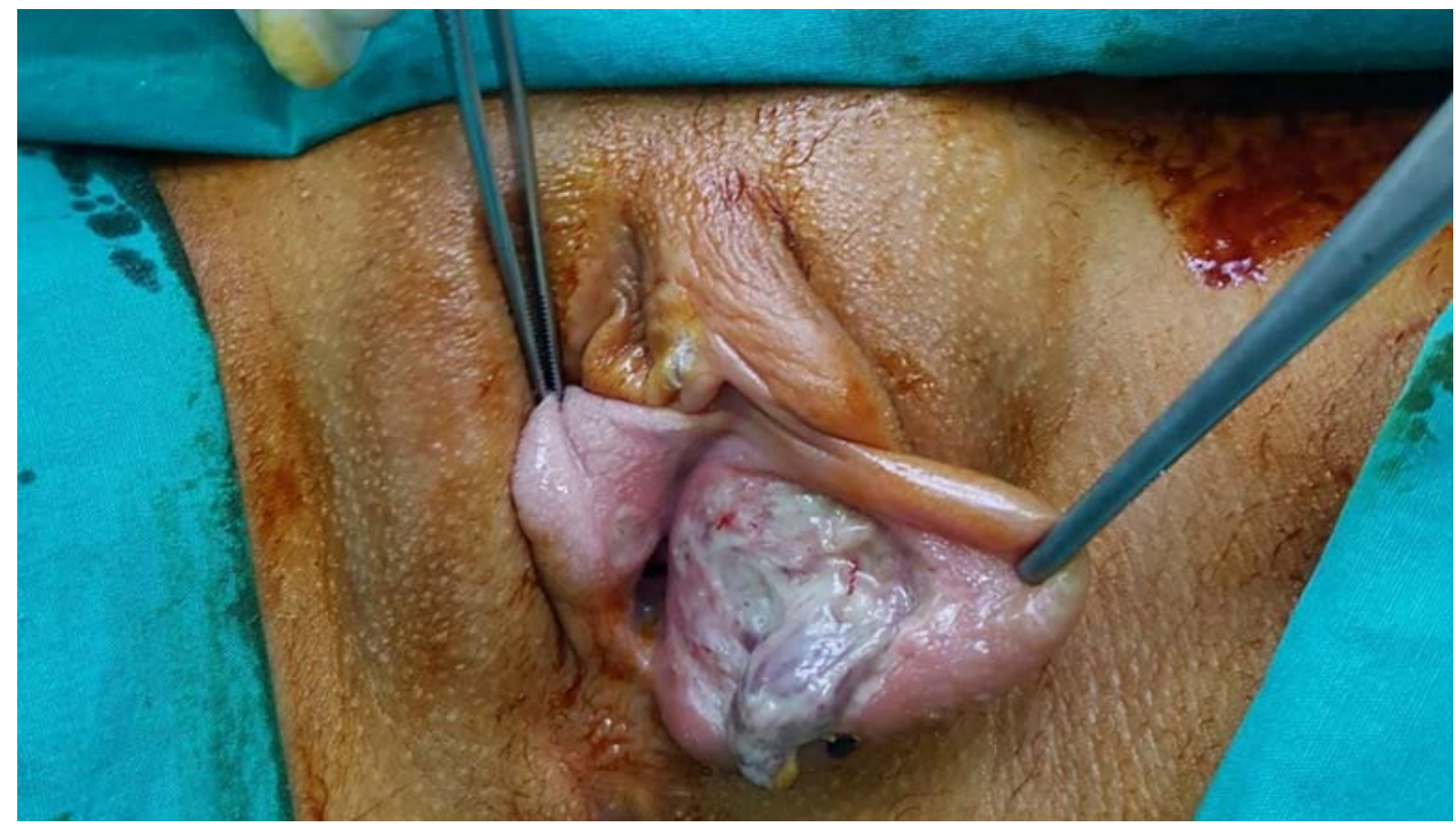

Figure 2. Swelling and inflammation in mainly inner side of left labia majora and a little lesion on the right side 
Her physical examination was unremarkable except fever $\left(37.8{ }^{\circ} \mathrm{C}\right)$ and ulcerative genital lesions. She was in good general condition. Ulcerated necrotic erythro lesions, located at the inner side of labia, had markedly limited irregular margins and were very painful with touching. There were no other skin or mucous membrane lesions. No vaginal discharge was noticed. On laboratory examination, C-reactive protein (35 $\mathrm{mg} / \mathrm{dL}$ ) was elevated, but there was no leukocytosis. Herpes simplex virus (HSV type 1 IgG positive, IgM negative), (HSV type 2 IgG negative, IgM negative), Cytomegalovirus (CMV IgG positive, IgM negative), Treponema pallidum (VDRL negative), Chlamydia trachomatis, Epstein-Barr virus infection (IgG negative, IgM negative, EBNA negative) and human immunodeficiency virus (HIV) serologies were all negative. Bacterial culture of the lesion was negative. A diagnostic biopsy was taken and the lesion debrided in the operating room (Figure 3). Pathologic examination revealed activation in chronic inflammation and granulation tissue with inflammation.

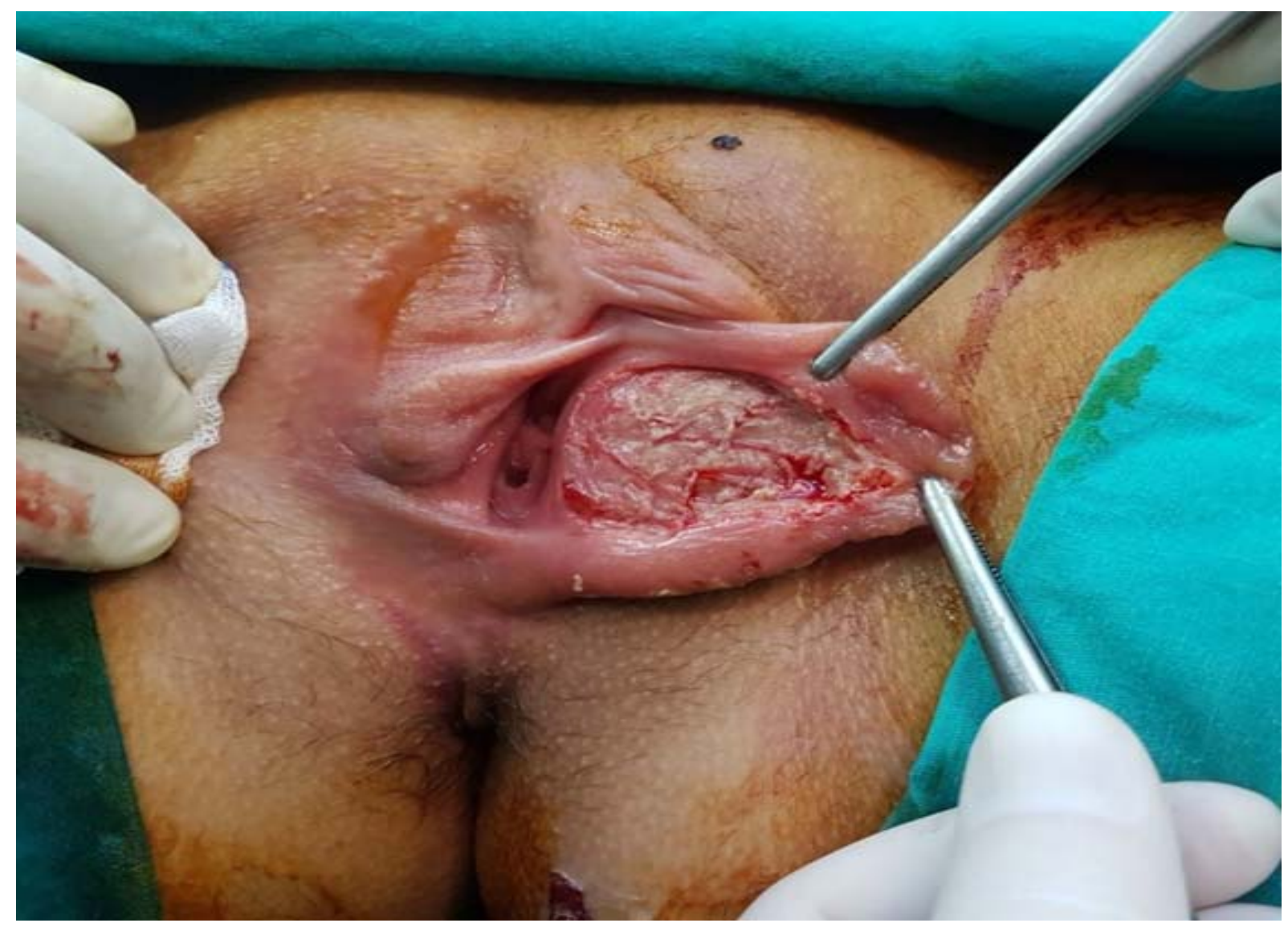

Figure 3. After debrided in operating room

She was treated with daily debridement of ulcerative lesion and wound management under anesthesia. Topical anesthetic cream (EMLA, Eutectic Mixture of Local Anesthetics) and topical antibacterial cream (Nitrofurazone) were applied. She had received iv imipenem ( $1 \mathrm{~g} /$ dose/day iv). She was discharged 1 week later and followed up (Figure 4). The lesion was completely healed 32 days. 


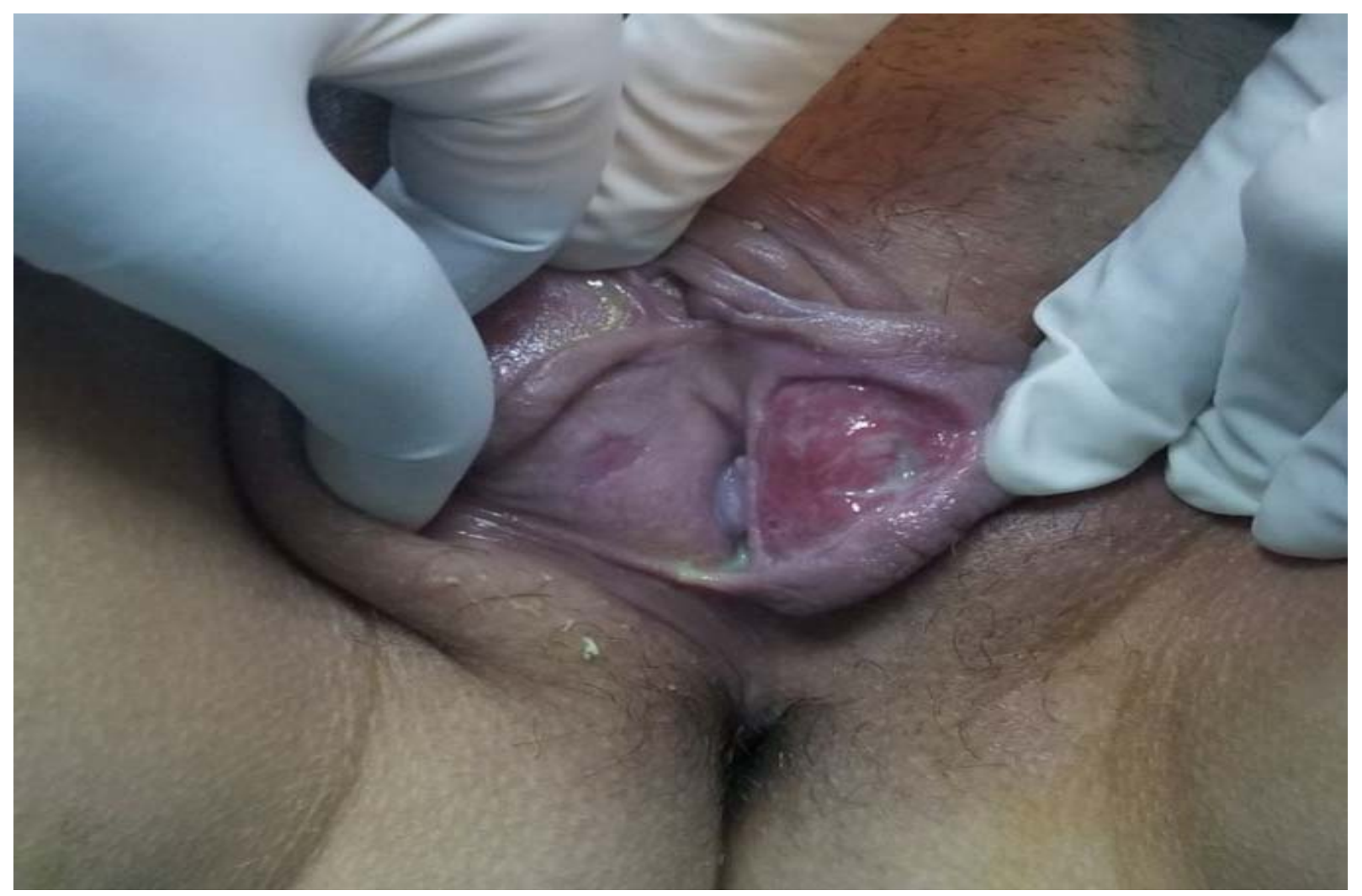

Figure 4. After resolution and treatment of Lipschütz

Informed written and oral consent was obtained from the patient for pictures and case presentation.

\section{Discussion}

In 1913, Lipschütz ulcer was first described as an acute clinical entity comprising of fever, necrotic painful genital ulcerations and lymphadenopathy in virgin adolescent girls. ${ }^{1}$ The disease is characterized by an acute onset of flu-like symptoms such as anxiety, fever, myalgia, pharyngotonsillitis, lymphadenopathy, and headache, with single or multiple, deep and painful mainly kissing ulcers on the vulva, on the inner side of labia majora. ${ }^{2}$ They usually occur in young women, predominantly in sexually non-active girls. ${ }^{3}$ Our case also presented similar findings. Ulcer in our case was larger than $1 \mathrm{~cm}$ and had sharply irregular borders, adherent grey-brown eschar, exudate (pseudomembrane), erythema and edematous lesions, in accordance with previous reports. 4

Acute genital ulcers are seldom encountered, especially sexually non-active girls and there are a few cases reported in the medical literature. ${ }^{5}$ Etiology and pathogenesis of AGU are still unknown but has been reported with infectious diseases essentially Epstein-Barr virus infection. EBV might reach the genital mucosa via hematogenous spread of EBV-infected lymphocytes or Langerhans cell precursors or through autoinoculation with saliva, urine, or cervicovaginal fluid. ${ }^{6}$ One hypothesis suggests that the ulcer is the clinical manifestation of a hypersensitivity reaction to a viral or bacterial infection, with deposition of immune complex in the dermal vessels, 
complement activation, microthrombosis, and subsequent tissue necrosis. ${ }^{7}$ The differential diagnosis includes venereal (sexually) and non-venereal (non-sexually) transmitted infections, non-infectious diseases, drug reactions, autoimmune conditions, local manifestations of systemic illnesses, as well as idiopathic aphthosis, traumatic causes and malignant tumors (Table 1). Initial workup may comprise complete blood cell count; bacterial culture; serological test for EBV, HIV, CMV, PCR assays for HSV, syphilis and skin biopsy from an ulcer edge if necessary. ${ }^{8}$ Other noninfectious causes of vulvar ulcers include drug reactions especially nonsteroidal anti-inflammatory drugs, Crohn's disease that is characterized by anal ulcers or fissures, Behçet's disease, and idiopathic aphthosis.

Table 1. Differential diagnosis of acute genital ulcer

\begin{tabular}{|c|c|c|c|c|}
\hline $\begin{array}{l}\text { Infectious } \\
\text { Venereal }\end{array}$ & Nonvenereal & Noninfectious & Traumatic & Malignant \\
\hline $\begin{array}{l}\text {-Herpes simplex } \\
\text { virus } \\
\text {-Syphilis } \\
\text {-HIV } \\
\text {-Granuloma } \\
\text { inguinale } \\
\text { - } \\
\text { Lymphogranuloma } \\
\text { venereum } \\
\text {-Chancroid }\end{array}$ & $\begin{array}{l}\text {-Epstein-Barr virus } \\
\text {-Candida } \\
\text {-Bacteria } \\
\text {-Parasites } \\
\text {-Mycobacteria }\end{array}$ & $\begin{array}{l}\text {-Drug reaction } \\
\text { (fixed drug } \\
\text { eruption, } \\
\text { erythema } \\
\text { multiforme, } \\
\text { Stevens-Johnson } \\
\text { syndrome) } \\
\text {-Pemphigus } \\
\text { vulgaris } \\
\text {-Bullous } \\
\text { pemphigoid } \\
\text {-Inflammatory } \\
\text { bowel disease } \\
\text {-Lichen planus } \\
\text {-Lichen sclerosus } \\
\text {-Idiopathic and } \\
\text { secondary aphthae } \\
\text {-Behcet's } \\
\text { syndrome } \\
\text {-Reiter syndrome } \\
\text {-Pyoderma } \\
\text { gangrenosum }\end{array}$ & $\begin{array}{l}\text {-Mechanical } \\
\text {-Thermal } \\
\text {-Chemical } \\
\text {-Factitial }\end{array}$ & $\begin{array}{l}\text {-Basal cell } \\
\text { carcinoma } \\
\text { tumors } \\
\text {-Squamous cell } \\
\text { carcinoma } \\
\text {-Extramammary } \\
\text { Paget's disease } \\
\text {-Leukemia/ } \\
\text { Lymphoma }\end{array}$ \\
\hline
\end{tabular}

The goals of treatment are to provide pain relief, improve healing and prevent scarring. If an underlying illness is found, treatment should be directed to the specific etiology, otherwise, anti-inflammatory drugs, analgesics and prophylactic broad-spectrum antibiotics (amoxicillin/clavulanic acid and azithromycin) are prescribed. Antiviral agents, such as acyclovir, are effective only in cases of documented HSV infection. Our patient also had no benefit from acyclovir use. Empiric treatment, such as sit-baths, may provide pain relief. We have performed daily cures under sedation in the operating to remove adherent necrotic material and administered imipenem. Oral corticosteroids and oral antibiotics can also be considered for peculiarly painful acute genital ulcers. The lesion was healed after mean times 16-21 days in our case. The condition is usually self-limited and healing is reported to be in 2 weeks, with low recurrence rate. $^{8}$ 
Lipschütz ulcers in sexually non-active girls should be carefully diagnosed and a detailed clinical examination and medical/sexual history along with laboratory tests should be undertaken for differential diagnosis. Child abuse should also be excluded. Our case report and literature review may be beneficial for documenting the natural history of Lipcshutz ulcers, as well as making a diagnosis, differential diagnosis, and treatment options.

\section{References}

1. Farhi D, Wendling J, Molinari E, et al. Non-sexually related acute genital ulcers in 13 pubertal girls: a clinical and microbiological study. Arch Dermatol. 2009;145:38-45.

2. Chanal J, Carlotti A, Laude H, Wallet-Faber N, Avril MF, Dupin N. Lipschütz genital ulceration associated whit mumps. Dermatology 2010;221:292-5.

3. Huppert JS, Gerber MA, Deitch HR, Mortensen JE, Staat MA, Adams Hillard PJ. Vulvar ulcers in young females: a manifestation of aphthosis. J Pediatr Adolesc Gynecol 2006;19: 195-204.

4. García Reymundo M, Montero Salas A, González Álvarez CM, Real TerrónÚlcera R. deLipchütz: causa poco conocida de úlcera genital aguda. An Pediatr 2010;72:443-4.

5. Barrett MM, Sangüeza M, Werner B, Kutzner H, Carlson JA. Lymphocytic arteritis in EpsteinBarr virus vulvar ulceration (Lipschütz disease): a report of 7 cases. Am J Dermatopathol 2015;37:691-8.

6. Di Lernia, V. and Y. Mansouri, Epstein-Barr virus and skin manifestations in childhood. Int J Dermatol 2013;52(10):1177-84.

7. Robert Sidbury, Moise L Levy, Rosamaria Corona, DSc Acute genital ulceration (Lipschütz ulcer). Up to Date Feb 2018 Available from: https://www.uptodate.com/contents/acute-genital-ulceration-lipschutz-ulcer

8. Özuğuz, Pınar, Seval Doğruk Kaçar, and Şemsettin Karaca. "Akut genital ülserlere (lipschutz ülser) yaklaşım." Journal of clinical obstetrics \& gynecology 23.2 (2013): 80-5. 